\title{
Seismic imaging of mid-crustal structure beneath central and eastern North America: Possibly the elusive Grenville deformation?
}

\author{
Maureen D. Long ${ }^{1}$, Margaret H. Benoit ${ }^{2}$, John C. Aragon ${ }^{1 *}$, and Scott D. King ${ }^{3}$ \\ 'Department of Geology and Geophysics, Yale University, New Haven, Connecticut 06520, USA \\ ${ }^{2}$ National Science Foundation, 2415 Eisenhower Avenue., Alexandria, Virginia 22314, USA \\ ${ }^{3}$ Department of Geosciences, Virginia Polytechnic Institute and State University, Blacksburg, Virginia 24061, USA
}

\begin{abstract}
The ca. 1 Ga Grenville orogeny was a protracted mountain-building event that culminated in the collision of Laurentia and Amazonia and the formation of the Rodinia supercontinent. While the expression of Grenville orogenesis in present-day crustal structure has been extensively investigated in eastern Canada, evidence for contemporaneous crustal deformation is less well established beneath the eastern United States. Furthermore, the interpretation of a geophysical lineament through the U.S. midcontinent, typically inferred to be the Grenville deformation front, has recently been called into question; an alternative hypothesis is that this feature actually corresponds to an eastern arm of the Midcontinent Rift. Here we present P-to-S receiver functions computed for stations of the Mid-Atlantic Geophysical Integrative Collaboration (MAGIC) experiment, a dense array of broadband seismometers across the central Appalachians and midcontinent. We see evidence for a crustal negative velocity gradient that dips gently (dip angle $<\mathbf{1 0}^{\circ}$ ) to the southeast and extends east from a location near the putative Grenville front, terminating near the Appalachian Mountains. While we cannot date this feature, its location and characteristics are consistent with a shallowly dipping, seismically anisotropic intracrustal shear zone associated with collisional deformation, perhaps during Grenville orogenesis. The similarity between this feature and similar mid-crustal detachments in other orogens, both ancient (Appalachians) and modern (Himalayas), suggests that this style of crustal deformation has been common in continental collisional orogens.
\end{abstract}

\section{INTRODUCTION}

Central and eastern North America exhibits extraordinarily complex geologic and tectonic structures, reflecting the influence of multiple processes. In particular, this region has been affected by two complete cycles of supercontinent assembly and breakup, encompassing the formation and dispersal of the Rodinia and Pangea supercontinents (e.g., Nance et al., 2014). The ca. $1 \mathrm{Ga}$ Grenville orogeny was associated with continent-continent collision during the formation of Rodinia (e.g., Rivers, 1997) and closely followed several other important tectonic events that affected Laurentia, including that which formed the Midcontinent Rift. The Midcontinent Rift, which formed at ca. $1.1 \mathrm{Ga}$ within Laurentia, consists of buried sedimentary and igneous rocks that find expression in

*Current address: Earthquake Science Center, U.S. Geological Survey, Menlo Park, California 94025, USA geophysical data (e.g., Stein et al., 2015), including Bouguer gravity anomalies (Fig. 1).

Processes associated with Grenville orogenesis have been thoroughly studied, particularly in southern Canada, where units of the Grenville province are exposed at the surface and extensive imaging of the crust was accomplished during the LITHOPROBE project (http:// lithoprobe.eos.ubc.ca/; for a review, see Rivers et al. [2012]). Considerably less is known about the architecture of the Grenville province, and processes associated with Grenville orogenesis, beneath the eastern United States. There is, in particular, vigorous debate about the existence, location, and nature of the Grenville front beneath this region (e.g., Stein et al., 2018). The front, considered to be the westward extent of Grenvillian deformation (e.g., Whitmeyer and Karlstrom, 2007), is a mapped boundary in eastern Canada (Fig. 1). Its assumed extension would lie under Paleozoic cover beneath the eastern United States (e.g., Rivers et al., 2012), so its location is typically inferred based on the character of gravity and magnetic anomalies. The Grenville front is thought to represent a reverse-sense shear zone (or set of shear zones), the location of which may have been controlled by preexisting structures (Rivers et al., 2012). Studies of the Grenville front across the United States-Canada border (the Great Lakes International Multidisciplinary Program on Crustal Evolution [GLIMPCE] project; Green et al., 1988; White et al., 2000; Fig. 1) using activesource imaging have interpreted the front as a southeast-dipping, crustal-scale ductile shear zone, shallowing into a regional mid-crustal décollement at a depth of $\sim 25-30 \mathrm{~km}$ (White et al., 2000). In this interpretation, the Grenville front and the nearby Allochthon Boundary thrust, a major shear zone internal to the orogen, accommodated northwest-directed crustal shortening and shearing during Grenville orogenesis (White et al., 2000; Rivers et al., 2012). To the south of the GLIMPCE line, data collected as part of the Consortium for Continental Reflection Profiling (COCORP, http://www .geo.cornell.edu/geology/cocorp/COCORP .html) effort (Fig. 1) indicate the presence of eastward-dipping reflectors; westward-dipping reflectors located to the east were interpreted as evidence for a doubly vergent orogen (Pratt et al., 1989; Culotta et al., 1990). Recently, Stein et al. (2018) argued that the Grenville front should be erased from the map in the eastern United States, partially on the grounds that seismic reflection data near the presumed front express markedly different geometries than the southeast-dipping, layered structures documented beneath the front in Canada. Stein et al. (2018) proposed that the gravity and magnetic anomalies that have been previously interpreted as part of the Grenville front beneath the midcontinent (Fig. 1) instead correspond to an eastern arm of the Midcontinent Rift. 
Figure 1. Bouguer anomaly map of the central and eastern United States, from the World Gravity Map (WGM2012) global gravity grid (http:// bgi.omp.obs-mip.fr/data-products /Grids-and-models/wgm2012; Bonvalot et al., 2012) upward continued to $40 \mathrm{~km}$, following Stein et al. (2014). Shaded regions (adapted from Stein et al., 2014) show particularly large gravity anomalies, including those that delineate the Midcontinent Rift. The Grenville front (GF) is shown as solid line where it is mapped in Canada and as a dashed line where it has been traditionally inferred (trad.) in the United States (Stein et al., 2014). Light-gray lines show state boundaries. Mid-Atlantic Geophysical Integrative Collaboration (MAGIC, http://www.tcnj.edu/ magic/MAGIC /Home.html) station locations are shown with stars. Thick gray lines show Consortium for Continental Reflection Profiling (COCORP-OH, http://www.geo.cornell.edu/geology/cocorp/COCORP.html) and Great Lakes International Multidisciplinary Program on Crustal Evolution (GLIMPCE) seismic lines.

Tectonic interpretations of Grenville-aged processes beneath the eastern United States, and their relationships with older Laurentian structures such as those of the Midcontinent Rift, have been hampered by a paucity of seismic data capable of resolving crustal-scale structures. With the advent of the EarthScope USArray (http://www.usarray .org) data set in eastern North America, additional data are now available, and broadband seismic deployments of the EarthScope USArray Flexible Array are enabling high-resolution crustal imaging and constraints on aspects of past tectonic processes that cannot be completely understood with geologic data alone. To highlight one recent example, Hopper et al. (2017) used data from the Southeastern Suture of the Appalachian Margin Experiment (SESAME, http://www.usarray.org /researchers/obs/flexible/deployments/sesame/) deployment in the southeastern United States to identify the Alleghanian Suwannee suture as a low-angle dipping interface that transitions into a flat-lying mid-crustal detachment, helping to distinguish among competing models for the last phases of Appalachian orogenesis. The recent deployment of the Mid-Atlantic Geophysical Integrative Collaboration (MAGIC, http://www.tenj .edu/ magic/MAGIC/Home.html) experiment (Aragon et al., 2017; Fig. 1) across the central Appalachians and into the midcontinent affords a similar opportunity to investigate deep crustal structure in the context of models for the Grenville orogeny and the Midcontinent Rift event.

\section{COMPLEX CRUSTAL STRUCTURE ACROSS THE MAGIC ARRAY}

We carried out P-to-S receiver function analysis beneath the MAGIC seismic transect to construct images of the crust beneath the array (Fig. 2). MAGIC crosses a number of important features (Fig. 2A), including the putative Grenville front, the Rome Trough (a Cambrian rift structure formed due to the breakup of Rodinia), and the Appalachian Mountains. The details of the data used and our methodology can be found in the GSA Data Repository ${ }^{1}$. The singlestation receiver function stacks, plotted as a function of distance along the transect in Figure 2C, indicate complex crustal structures beneath the MAGIC array. The Moho is visible as a strong positive (red in Fig. 2) pulse with a depth varying between $\sim 32 \mathrm{~km}$ and $\sim 58 \mathrm{~km}$, with the thickest crust located $\sim 200 \mathrm{~km}$ from the western end of the transect; thick crust is also found beneath the Appalachian Mountains. In contrast, relatively thinner crust is found beneath the eastern end of the profile and beneath the Rome Trough, $\sim 420-480 \mathrm{~km}$ from the western end. Detailed investigations of crustal thickness and its implications for density and isostasy beneath the central Appalachians will be presented elsewhere, but the considerable variations in Moho depth suggest variability in crustal density along the profile.

Other than those associated with the Moho, the most prominent arrivals on the single-station stacks are a series of negative (blue in Fig. 2) arrivals, indicating a sharp decrease in velocity with depth, visible in the western half of the transect. The moveout of these arrivals (see the Data Repository) suggests that they are primary conversions and do not result from multiple reflections within shallower layers. The apparent depth of the sharp velocity contrast is $\sim 10 \mathrm{~km}$ or less near the western end of the array,

${ }^{1}$ GSA Data Repository item 2019127, data and methodological details, and supplementary figures and table, is available online at http://www.geosociety.org /datarepository/2019/, or on request from editing@ geosociety.org. and it gradually deepens to $\sim 30 \mathrm{~km}$ beneath the array midpoint. The lateral continuity of this feature is lost beneath the Appalachian Mountains (Fig. 2C). The complex character of arrivals in the receiver function stacks beneath the Appalachian Mountains is consistent with significant intracrustal layering, which may obscure the structure in this region.

The prominent mid-crustal feature is also visible on the common conversion point stack (Fig. 2E), where it manifests as a prominent negative (blue) interface that is continuous along the profile and can be traced from the western portion of the image $\sim 400 \mathrm{~km}$ to the east. The feature extends nearly horizontally at a depth of $\sim 10 \mathrm{~km}$ from a distance of $\sim 100 \mathrm{~km}$ from the western end of the MAGIC profile to a point $\sim 200 \mathrm{~km}$ along it. Further to the east, it dips to the southeast, deepening from $\sim 10 \mathrm{~km}$ to $\sim 30 \mathrm{~km}$ over a distance of $\sim 200 \mathrm{~km}$ (apparent dip angle of $\sim 6^{\circ}$ ), then transitions to a nearly horizontal interface at a depth of $\sim 30 \mathrm{~km}$. The flat portion of the interface here lies just to the west of the relatively high topography of the Appalachian Mountains, and the mid- to upper crust in this region exhibits significant complexity, with a series of prominent flat-lying positive and negative interfaces at depths between $\sim 10$ and $30 \mathrm{~km}$.

In order to test hypothetical structures that could yield the receiver function patterns visible in Figure 2, we carried out forward modeling of our data, described in detail in the Data Repository. Based on this modeling, and following the interpretation of Hopper et al. (2017) for a similar feature observed beneath the southern Appalachians, our preferred model invokes an anisotropic shear zone ( $20 \%$ seismic velocity anisotropy) with a slow axis of symmetry oriented perpendicular to the shear zone. A positive (red) pulse visible just above the prominent negative (blue) pulse at stations in the central part of the array (Fig. 2) may correspond to the top of the shear zone (see synthetics in Fig. DR8 in the Data Repository). We acknowledge that there are other models that could explain our observations, including those that invoke the presence of an isotropic layer with a different seismic velocity in the mid-crust; these are discussed in detail in the Data Repository.

We compare the geometry of the mid-crustal negative velocity gradient imaged beneath the MAGIC array with previous imaging studies using active-source COCORP data (Pratt et al., 1989; Culotta et al., 1990; Baranoski et al., 2009; Fig. 1). Culotta et al. (1990) identified mid-crustal reflectors beneath the western portion of our array that dip steeply to the east at dip angles of $\sim 25^{\circ}-30^{\circ}$, along with westwarddipping reflectors further to the east. The view of intracrustal structure afforded by the passivesource MAGIC array is considerably different; instead of steeply dipping interfaces suggesting 
Figure 2. P-wave receiver function images across the Mid-Atlantic Geophysical Integrative Collaboration (MAGIC, http://www.tcnj.edu I magic/M AGIC/Home .html) array. A: Map of seismic stations (triangles) used in the analysis, including MAGIC array (red), USArray Transportable Array (TA, blue), and U.S. Network (black). Background colors indicate topography. Dashed lines show major tectonic features, including the putative Grenville front (GF; black) as in Stein et al. (2018), boundaries of the Rome Trough (RT; magenta), and the Appalachian front (AF; white) from Whitmeyer and Karlstrom (2007). Thin black lines indicate state boundaries. Black dots show end points of transect shown in panels $B-F$. B: Topographic profile, with triangles indicating station locations and vertical lines indicating locations of major tectonic features, labeled as in A. C: Single-station stacked radial receiver function traces, migrated to depth $(y$-axis, in $\mathrm{km})$ and plotted at station
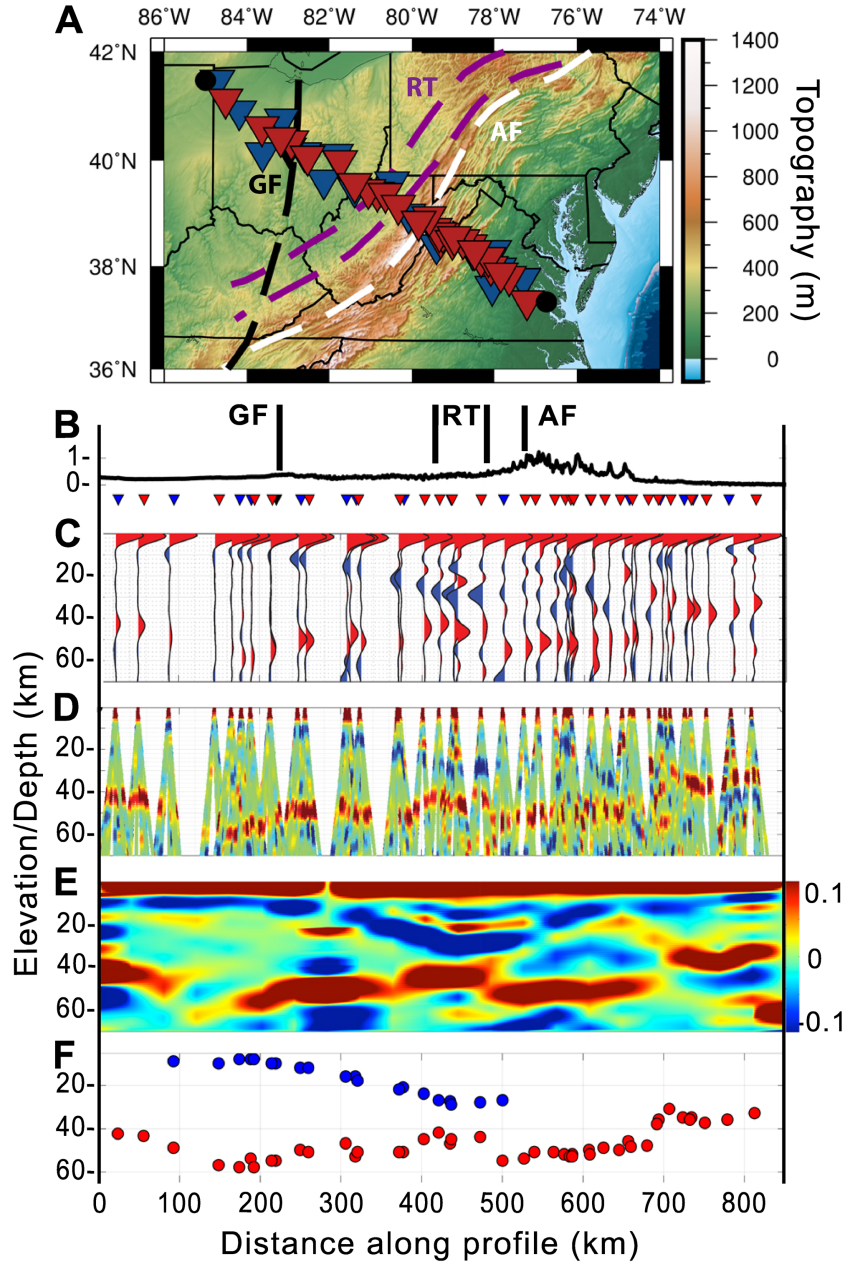

location (distance along transect on $\mathrm{x}$-axis, in $\mathrm{km}$ ). Note vertical exaggeration of the image. Red pulses correspond to a positive velocity gradient with depth; blue pulses correspond to a negative velocity gradient. D: Individual receiver function traces plotted along lines representing raypaths of individual phase arrivals. E: Corresponding common conversion point stacked image across transect; color conventions are as in $C$ and $D$, with amplitudes indicated by color bar at right (expressed as fractions of main P-wave amplitude). F: Estimated depth of Moho (red dots) and inferred mid-crustal shear zone (blue dots) beneath each station.

a doubly vergent geometry, we image a gently southeastward-dipping interface that extends to the east, past the coverage of the COCORP lines. The geometry of our mid-crustal interface is, however, generally similar to the geometry of the inferred Grenville front tectonic zone-Allochthon Boundary thrust, as inferred from imaging beneath the GLIMPCE line (White et al., 2000), $\sim 400 \mathrm{~km}$ to the north of our study region. In both cases, there is evidence for a dipping interface that transitions into a nearly horizontal midcrustal feature, although the apparent dip of the interface beneath MAGIC is considerably shallower at its western end than the corresponding feature beneath the GLIMPCE line. This may reflect differences in the ability of active- versus passive-source imaging techniques to characterize structure in the shallow $(<10 \mathrm{~km})$ portions of the crust. Specifically, a combination of differences in the experiment geometries (and thus resolution) and different frequency content of the waves may explain the discrepancies.

\section{IMPLICATIONS FOR THE GRENVILLE FRONT DEBATE}

Given the position and geometry of the midcrustal negative velocity gradient imaged beneath the MAGIC line, our preferred interpretation is that this feature corresponds to the main deformation front of the Grenville orogen beneath our study region. Specifically, its proximity at its shallowest point to the putative Grenville front (Fig. 2), its general similarity to the imaged geometry of the front beneath the GLIMPCE line (White et al., 2000), and its extension far to the east of gravity anomalies that may be associated with the Midcontinent Rift (Fig. 1) argue for this interpretation. In this view, it is analogous to structures of the Grenville front and the closely related Allochthon Boundary thrust imaged farther to the north in Canada (e.g., Rivers et al., 2012). Alternative explanations may also be possible; we considered the idea that the feature may reflect a boundary between different terranes at depth (perhaps involving the Mazatzal terrane; Petersson et al.,
2015). However, the presence of the mid-crustal feature along $400 \mathrm{~km}$ of the MAGIC profile, extending as far east as the Appalachian Mountains, makes this scenario less likely.

We propose that the mid-crustal feature imaged beneath the MAGIC line represents a zone of highly sheared and foliated crustal rocks that accommodated the considerable shortening (e.g., Halls, 2015) associated with continental collision during the formation of Rodinia. Based on geophysical imaging alone, we cannot say whether this shear zone corresponds to the Grenville front itself, to a related structure such as the Allochthon Boundary thrust, or to relatively diffuse crustal deformation within the Grenville front tectonic zone (see, e.g., Rivers et al., 2012). In any case, the strong foliation and anisotropy needed to produce the apparent velocity contrast suggested by forward modeling of our observations (Fig. DR8) is consistent with high-strain deformation accommodated along this midcrustal boundary. Interestingly, the feature we image cuts across the Rome Trough, which in our interpretation is a younger structure; this suggests that any crustal thinning or extension associated with Cambrian rifting had a limited effect on preexisting mid-crustal structure.

Geophysical images of the present-day structure of a mid-crustal shear zone associated with Grenville orogenesis cannot constrain the timing of the inferred deformation. As pointed out by Stein et al. (2018), some aspects of detrital zircon dating work (Schneider Santos et al., 2002; Malone et al., 2016) challenge the idea that compressional faulting beneath the western end of the MAGIC array was contemporaneous with Grenville compression to the north in Canada, and instead suggest that it may be younger (perhaps by hundreds of millions of years; Malone et al., 2016). A difference in the timing of collisional events associated with Rodinia supercontinent formation can be accommodated by our conceptual model, as the geophysical images constrain only the presence and location of the crustal shear zone today. As noted by Stein et al. (2018), the Grenville orogen serves as a prime illustration of the spatial and temporal complexity of orogenic belts, and the timing of compressional deformation associated with Rodinia's formation likely varied along the Laurentian margin, perhaps with later collision beneath our study region than farther to the north in Canada.

Our image of a mid-crustal feature beneath the MAGIC array is relevant to the ongoing debate regarding structures of the Midcontinent Rift and the putative Grenville front beneath the central and eastern United States Stein et al. (2018) recently proposed that the potential field anomalies (gravity and magnetics) that delineate the "Grenville front" beneath the United States may actually correspond to structures associated with an eastern branch of the Midcontinent Rift, and may not be associated with 
Grenville orogenesis at all. As pointed out by Stein et al. (2018), the mapped Grenville front in Canada does not find clear expression in geophysical data; furthermore, gravity anomalies in the United States mid-continent (Fig. 1) may represent dense mafic underplating due to volcanism associated with the Midcontinent Rift, rather than Grenville-aged structures. Stein et al. (2018) further argued that the dissimilarity in crustal imaging results beneath the central and eastern United States (based on COCORP data) and southern Canada (based on LITHOPROBE data) point to a different set of processes controlling crustal structure. Our results do not conflict with the main thrust of the arguments about the nature of the Midcontinent Rift made by Stein et al. (2018), and do not shed any light on the nature of the putative Grenville front elsewhere beneath the United States They do, however, establish evidence for a crustal-scale shear zone or detachment beneath the MAGIC study region that likely accommodated the deformation associated with continental collision and shortening during the formation of Rodinia. Furthermore, the general similarity between our image and that of the Grenville front beneath the GLIMPCE line (White et al., 2000) contradicts one of the lines of evidence argued by Stein et al. (2018). While the timing of collisional deformation beneath the central and eastern United States may well have been different than in the mapped portions of the Grenville orogen in Canada, the geometry of the deformation front, as manifested in a crustal-scale shear zone that extends over several hundred kilometers, may have been similar.

\section{DEFORMATION STRUCTURES COMPARED ACROSS COLLISIONAL OROGENS}

The mid-crustal shear zone imaged beneath the MAGIC array bears a striking similarity to crustal structures in other orogenic settings, both ancient and modern (e.g., the Alleghanian suture beneath the southeastern United States or the main Himalayan thrust beneath India; Hopper et al., 2017; Schulte-Pelkum et al., 2005). The similarity between the inferred geometry of the Alleghanian suture and images of the main Himalayan thrust, with a gently dipping shear zone shallowing into a nearly flat mid-crustal detachment, was pointed out by Hopper et al. (2017). They further argued that the similarity in these structures pointed to the persistence of similar styles of crustal deformation during mountain building, and similar crustal rheologies, over hundreds of millions of years. The images of the Grenville deformation front presented here extend this comparison back in time, suggesting that this mode of crustal deformation during continental collisional orogenesis may have persisted on Earth back to the middle Proterozoic.

\section{ACKNOWLEDGMENTS}

Seismic data from the USArray Transportable Array, the U.S. National Seismic Network, and the Mid-Atlantic Geophysical Integrative Collaboration (MAGIC) experiment (https://doi.org/10.7914/SN/7A 2013) were accessed via the Data Management Center (http://ds.iris.edu) of the Incorporated Research Institutions for Seismology (IRIS). The MAGIC deployment was supported by the IRIS PASSCAL Instrument Center at the New Mexico Institute of Mining and Technology, Socorro, New Mexico, USA. The facilities of the IRIS Consortium are supported by the U.S. National Science Foundation (NSF) under Cooperative Agreement EAR-1261681 and the U.S. Department of Energy National Nuclear Security Administration. The MAGIC project was supported by the EarthScope and GeoPRISMS programs of the NSF via grant EAR1251515 to Yale University, grant EAR-1251329 to the College of New Jersey, and grant EAR-1250988 to Virginia Polytechnic Institute and State University. The Generic Mapping Tools (Wessel and Smith, 1991) and FuncLab (Porritt and Miller, 2018) software programs were used in this work. The NSF I/D program helped support preparation of this manuscript. Any opinion, findings, and conclusions or recommendations expressed in this article are those of the authors and do not necessarily reflect the views of the NSF. We gratefully acknowledge comments from editor Dennis Brown, Carol Stein, and two anonymous reviewers.

\section{REFERENCES CITED}

Aragon, J.C., Long, M.D., and Benoit, M.H., 2017, Lateral variations in $S K S$ splitting across the MAGIC array, central Appalachians: Geochemistry Geophysics Geosystems, v. 18, p. 4136-4155, https://doi.org/10.1002/2017GC007169.

Baranoski, M.T., Dean, S.L., Wicks, J.L., and Brown, V.M., 2009, Unconformity-bounded seismic reflection sequences define Grenville-age rift system and foreland basins beneath the Phanerozoic in Ohio: Geosphere, v. 5, p. 140-151, https://doi .org/10.1130/GES00202.1

Bonvalot, S., Balmino, G., Briais, A., Kuhn, M., Peyrefitte, A., Vales, N., Biancale, R., Gabalda, G., Moreaux, G., Reinquin, F., and Sarrahilh, M., 2012, World Gravity Map: Paris, France, Commission for the Geological Map of the World, BGICGMW-CNES-IRD, 3 sheets, scale 1:50,000,000.

Culotta, R.C., Pratt, T., and Oliver, J., 1990, A tale of two sutures: COCORP's deep seismic surveys of the Grenville province in the eastern U.S. midcontinent: Geology, v. 18, p. 646-649, https:// doi.org/10.1130/0091-7613(1990)018<0646: ATOTSC $>2.3 . \mathrm{CO} ; 2$.

Green, A.G., Milkereit, B., Davidson, A., Spencer, C., Hutchinson, D.R., Cannon, W.F., Lee, M.W., Agena, W.F., Behrendt, J.C., and Hinze, W.J., 1988, Crustal structure of the Grenville front and adjacent terranes: Geology, v. 16, p. 788-792, https://doi.org/10.1130/0091-7613(1988)016 $<0788$ :CSOTGF>2.3.CO;2.

Halls, H.C., 2015, Paleomagnetic evidence for $\sim 4000 \mathrm{~km}$ of crustal shortening across the $1 \mathrm{Ga}$ Grenville orogen of North America: Geology, v. 43, p. 1051-1054, https://doi.org/10.1130/G37188.1.

Hopper, E., Fisher, K.M., Wagner, L.S., and Hawman, R.B., 2017, Reconstructing the end of the Appalachian orogeny: Geology, v. 45, p. 15-18, https://doi.org/10.1130/G38453.1.

Malone, D.H., Stein, C.A., Craddock, J.P., Kley, J., Stein, S., and Malone, J.E., 2016, Maximum depositional age of the Neoproterozoic Jacobsville Sandstone: Implications for the evolution of the Midcontinent Rift: Geosphere, v. 12, p. 12711282, https://doi.org/10.1130/GES01302.1.

Nance, R.D., Murphy, J.B., and Santosh, M., 2014, The supercontinent cycle: A retrospective essay:
Gondwana Research, v. 25, p. 4-29, https://doi .org/10.1016/j.gr.2012.12.026.

Petersson, A., Scherstén, A., Andersson, J., Whitehouse, M.J., and Baranoski, M.T., 2015, Zircon $\mathrm{U}-\mathrm{Pb}, \mathrm{Hf}$ and $\mathrm{O}$ isotope constraints on growth versus reworking of continental crust in the subsurface Grenville orogeny, Ohio, USA: Precambrian Research, v. 265, p. 313-327, https://doi .org/10.1016/j.precamres.2015.02.016.

Porritt, R.W., and Miller, M.S., 2018, Updates to FuncLab, a Matlab based GUI for handling receiver functions: Computers \& Geosciences, v. 111 , p. $260-271$, https://doi.org/10.1016/j .cageo.2017.11.022.

Pratt, T., Culotta, R., Hauser, E., Nelson, D., Brown, L., Kaufman, S., Oliver, J., and Hinze, W., 1989, Major Proterozoic basement features of the eastern midcontinent of North America revealed by recent COCORP profiling: Geology, v. 17, p. 505-509, https://doi.org/10.1130/0091-7613 (1989)017<0505:MPBFOT>2.3.CO;2.

Rivers, T., 1997, Lithotectonic elements of the Grenville Province: Review and tectonic implications: Precambrian Research, v. 86, p. 117-154, https:// doi.org/10.1016/S0301-9268(97)00038-7.

Rivers, T., Culshaw, N., Hynes, A., Indares, A., Jamieson, R., and Martignole, J., 2012, The Grenville Orogen-A post-LITHOPROBE perspective, in Percival, J.A., Cook, F.A., and Clowes, R.M., eds., Tectonic Styles in Canada: The LITHOPROBE Perspective: Geological Association of Canada Special Paper 49, p. 97-236.

Schneider Santos, J.O., Hartmann, L.A., McNaughton, N.J., Easton, R.M., Rea, R.G., and Potter, P.E., 2002, Sensitive high resolution ion microprobe (SHRIMP) detrital zircon geochronology provides new evidence for a hidden Neoproterozoic foreland basin to the Grenville Orogen in the eastern Midwest, USA: Canadian Journal of Earth Sciences, v. 39, p. 1505-1515, https://doi .org/10.1139/e02-052.

Schulte-Pelkum, V., Monsalve, G., Sheehan, A., Pandey, M.R., Sapkota, S., Bilham, R., and Wu, F., 2005, Imaging the Indian subcontinent beneath the Himalaya: Nature, v. 435 , p. $1222-1225$, https://doi.org/10.1038/nature03678.

Stein, C.A., Stein, S., Merino, M., Keller, G.R., Flesch, L.M., and Jurdy, D.M., 2014, Was the Midcontinent Rift part of a successful seafloorspreading episode?: Geophysical Research Letters, v. 41, p. 1465-1470, https://doi.org/10.1002 /2013GL059176.

Stein, C.A., Kley, J., Stein, S., Hindle, D., and Keller, G.R., 2015, North America's Midcontinent Rift: When rift met LIP: Geosphere, v. 11, p. 16071616, https://doi.org/10.1130/GES01183.1.

Stein, C.A., Stein, S., Elling, R., Keller, G.R., and Kley, J., 2018, Is the "Grenville Front" in the central United States really the Midcontinent Rift?: GSA Today, v. 28 , no. 5, p. 4-10, https://doi.org /10.1130/GSATG357A.1.

Wessel, P., and Smith, W.H.F., 1991, Free software helps map and display data: Eos (Transactions, American Geophysical Union), v. 72, p. 441-446, https://doi.org/10.1029/90EO00319.

White, D.J., Forsyth, D.A., Asudeh, I., Carr, S.D., Wu, H., Easton, R.M., and Mereau, R.F., 2000, A seismic-based cross-section of the Grenville Orogen in southern Ontario and western Quebec: Canadian Journal of Earth Sciences, v. 37, p. 183-192, https://doi.org/10.1139/e99-094.

Whitmeyer, S.J., and Karlstrom, K.E., 2007, Tectonic model for the Proterozoic growth of North America: Geosphere, v. 3, p. 220-259, https://doi.org /10.1130/GES00055.1.

Printed in USA 